ROCZNIKI FILOZOFICZNE

Tom LXVII, numer $2-2019$

DOI: http://dx.doi.org/10.18290/rf.2019.67.2-6

ANNA KRAJEWSKA

\title{
PROBLEM ODPOWIEDZIALNOŚCI ZA PRZYPADKOWE SKUTKI DZIAŁANIA
}

Nierzadko zdarzają się sytuacje, kiedy człowiek w sposób niezamierzony powoduje zaistnienie negatywnych skutków. „Ale ja tego nie chciałem”, „skąd miałam wiedzieć, że to się tak skończy” - tych i podobnych sformułowań używamy, aby powiedzieć, że powstała strata nie była wynikiem naszego zamierzonego działania. Nastąpił nieszczęśliwy zbieg okoliczności. To niezależne, niekontrolowane przez nas czynniki spowodowały dane stany rzeczy. Jeśli skutki nie były wyrazem naszej intencji, były poza naszą kontrolą, to sprawca nie powinien za nie moralnie odpowiadać. O odpowiedzialności moralnej mówimy tylko wtedy, gdy podmiot działał świadomie i dobrowolnie, a skutki działania pojawiły się jako wynik decyzji.

Czy rzeczywiście nie możemy oczekiwać od podmiotu, że weźmie on odpowiedzialność za przypadkowe skutki swojego działania? Odwołajmy się do przykładu. Kierowca wyjeżdża na drogę. Jedzie w sposób przepisowy, ale nagle na jezdnię wbiega dziecko. Próbuje wyhamować, ale mu się to nie udaje i doprowadza do wypadku. Nie da się zaprzeczyć, że kierowca spowodował śmierć dziecka, chociaż nie była ona przez niego zamierzona. Dziecko pojawiło się na drodze niezależnie od intencji kierowcy. Tym niemniej, chociaż skutek nie był przez podmiot zamierzony, jego działanie przyczyniło się do tragedii. Czy nie jest zatem tak, że chociaż skutki podejmowanego przez podmiot działania zależą od czynników, na które on nie miał wpływu, to mimo to może być on adresatem uzasadnionych roszczeń moralnych? Kierowcy nie możemy moralnie obwiniać za śmierć dziecka, czy nie możemy jednak oczekiwać od niego wzięcia odpowiedzialności za to wydarzenie?

Dr AnNA KRAJEwSKA - Katolicki Uniwersytet Lubelski Jana Pawła II, Wydział Filozofii, Instytut Filozofii Teoretycznej, Katedra Etyki Szczegółowej; Al. Racławickie 14, 20-950 Lublin; e-mail: anna.krajewska@op.pl; ORCID: https://orcid.org/0000-0003-2795-1263. 
Warto zaznaczyć, że mówiąc o odpowiedzialności, można mieć na myśli różne jej postacie. Odwołajmy się do Romana Ingardena, wyróżniającego cztery sytuacje, w których pojawia się fenomen odpowiedzialności:

1. Ktoś ponosi odpowiedzialność za coś, czyli jest za coś odpowiedzialny.

2. Ktoś bierze odpowiedzialność za coś.

3. Ktoś jest za coś pociagany do odpowiedzialności.

4. Ktoś działa odpowiedzialnie. (INGARDEN 1973, 78).

We wszystkich tych sytuacjach ujawnia się wspólny sens słowa odpowiedzialność. Wskazuje na to sama etymologia. Rdzeniem słowa odpowiedzialność w języku polskim jest rzeczownik odpowiedź czy czasownik odpowiadać. Odpowiedzialność jest zatem formą odpowiedzi człowieka na jakąś sytuację. Podmiot, pozostając w jakiejś relacji do zaistniałych stanów rzeczy, ma obowiązek na nie zareagować. Sama sytuacja domaga się zatem udzielenia właściwej odpowiedzi.

Korzystając z rozróżnień zaproponowanych przez Ingardena, spójrzmy na przypadek kierowcy. Trudno obwiniać kierowcę za śmierć dziecka. Z całą pewnością nie ponosi on odpowiedzialności moralnej za wypadek. Tym samym kierowca nie może być do takiej odpowiedzialności pociągnięty. Uznajemy, że na ile mógł, kierowca działał odpowiedzialnie, sprawdził uprzednio stan hamulców, był uważny i skupiony, jechał zgodnie z przepisami itd. Próbując ująć kontekst, w którym można by mówić o odpowiedzialności kierowcy (bez ponoszenia winy), pozostaje sytuacja wyróżniona przez Ingardena w punkcie 2:

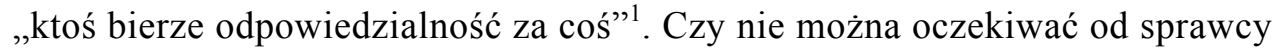
wypadku, że weźmie zań odpowiedzialność, nawet jeśli nie można mu przypisać odpowiedzialności moralnej?

W swoim artykule chciałabym przedstawić racje za tym, że moralnie pożądaną odpowiedzią podmiotu na spowodowaną w sposób niezamierzony stratę jest wzięcie za nią odpowiedzialności. Odpowiedzialność ta nie jest wynikiem zaciagnniętej winy, nie jest także wyłącznie wyrazem moralnej wrażliwości podmiotu, ale ma swoje obiektywne podstawy. Z jednej strony jest on zobowiązany do takiej decyzji ze względu na konieczność zachowania swojej integralności podmiotowej, z drugiej strony, ze względu na obiektywny charakter relacji łączącej jego działanie z zaistniałą stratą. Racje wskazujące na istnienie moralnego obowiązku wzięcia odpowiedzialności za niedobrowolne skutki działań tkwią w samym podmiocie i jego relacji do

\footnotetext{
${ }^{1}$ Ingarden pisze, że „można brać za coś odpowiedzialność, przy czym nie jest się rzeczywiście za to odpowiedzialnym". (INGARDEN 1973, 78).
} 
nich, a także w samej specyfice działania. Wskazane podwójne racje wyznaczają porządek analiz niniejszego artykułu.

\section{PODMIOT DZIAŁANIA A POWODOWANE SKUTKI}

\section{A. Dziąanie a skutKi przypadKowe}

W analizowanym przykładzie to kierowca, czyli określony podmiot, spowodował zaistnienie jakichś negatywnych konsekwencji. Stwierdzenie, że ,zdarzył się wypadek”, nie oddaje faktu, że to konkretny „ktoś” spowodował określone rezultaty, nawet jeśli spowodował je nieumyślnie. Opis wypadku w postaci stwierdzeń: „coś się stało”, „coś się wydarzyło”, czyli opis w kategoriach rzeczowych, pozaosobowych, nie wydaje się opisem adekwatnym. Czasem, kiedy nie dysponujemy wiedzą o tym, kto spowodował dane skutki, stwierdzamy: „zdarzył się wypadek”. Stwierdzenie to jednak tylko wtedy pozostaje w mocy, kiedy nie potrafimy wskazać przyczyny. Wraz z poznaniem okoliczności sytuacji, język pozaosobowy przestaje być właściwy. Spowodowanie wypadku istotnie różni się od zaistnienia niezależnych od człowieka zjawisk, zdarzeń, jak np. uderzenie meteorytu w ziemię. Kiedy mówimy, że spadające drzewo zrobiło dziurę w dachu, a przez Kanadę przeszło tornado, opisujemy te zdarzenia jako „coś się stało”, ponieważ zjawiska te nie miały nic wspólnego z działaniem podmiotu (zakładając, że człowiek nie obalił drzewa i nie wywołał tornada). Wobec takich sytuacji podmiot pozostaje biernym obserwatorem, jest jedynie świadkiem jakichś zdarzeń. W przeciwieństwie do tego kierowca $\mathrm{z}$ naszego przykładu pozostaje $\mathrm{w}$ relacji przyczynowej do powstałego zdarzenia, to on bowiem je spowodował, a nie jakiś czynnik niezależny od ludzkiej aktywności.

Przypadkowe skutki działania pozostają w związku z tymże działaniem. Kierowca i jego działanie pozostają w przyczynowej relacji do zaistniałego wypadku. Związek podmiotu ze skutkami swoich działań nie jest taki sam jak np. związek podmiotu $\mathrm{z}$ rozgrywającymi się $\mathrm{w}$ jego organizmie procesami biologicznymi. Przyczynowanie przypadkowego skutku nie jest analogiczne do zachodzenia niekontrolowalnych dynamizmów, wobec których podmiot pozostaje całkowicie bierny. Do takich dynamizmów zaliczamy np. uczynnienia (WoJtYŁa 1994, 118). Uczynnienie, jak podkreśla Karol Wojtyła, to pewien wewnętrzny dynamizm występujący w człowieku, który można określić jako to, „co się we mnie dzieje”. Człowiek biernie podlega pewnym procesom. 
Mimo że uczynnienia nie mają nic wspólnego z podjętym przez podmiot działaniem, człowiek jednak ma świadomość, że to on jest ich przyczyną, w nim bowiem owe dynamizmy się „dzieja”.

Podobnie pewnym biernym dynamizmem, któremu człowiek podlega, jest np. potknięcie się i nieumyślne potrącenie drugiego człowieka. Zarówno potrącenie, jak i potknięcie się nie jest skutkiem działania podmiotu. Tym niemniej podmiot czuje się zobligowany do przeproszenia potrąconej osoby. Przeproszenie $\mathrm{w}$ takiej sytuacji jest jednocześnie wskazaniem na brak intencjonalności w powodowaniu skutku. Gest ten ujawnia, że podmiot ma świadomość związku z zaistniałą sytuacją ${ }^{2}$.

W przypadkowym powodowaniu straty, podobnie jak w uczynnieniu czy mimowolnych reakcjach ciała, podmiot pozbawiony jest kontroli nad skutkami swoich dynamizmów. Brak kontroli dotyczy jednak tylko pewnych skutków, a nie całego działania. Podmiot bowiem jest sprawcą działania, podją je w sposób dobrowolny. Kierowca świadomie i dobrowolnie wyjechał na drogę. Obok zamierzonych skutków tego działania pojawiły się także przypadkowe. W sytuacji wypadku nie można powiedzieć, że kierowca zupełnie nie sprawuje kontroli nad swoim działaniem. Relacja kierowcy do skutków swojego działania nie może więc zostać potraktowana tak samo jak jego relacja do mimowolnych uczynnień czy bezwolnych reakcji cielesnych. Różny charakter relacji domaga się różnych odpowiedzi podmiotu. O ile w przypadku mimowolnego potrącenia kogoś wystarczą konwencjonalne przeprosiny, o tyle są one zdecydowanie niewystarczające w nieumyślnie spowodowanej szkodzie, zwłaszcza jeśli szkoda ta jest moralnie doniosła, a taką niewątpliwie jest śmierć dziecka³ ${ }^{3}$.

\section{B. Struktura podmiotu dziatania}

Choć istnieje różnica między działaniem, nieumyślnym powodowaniem skutków a uczynnieniami i mimowolnymi reakcjami ciała, to trzeba podkreślić, że źródłem ich wszystkich jest jeden i ten sam człowiek. Doświadcza on i przeżywa jedność swego podmiotowania zarówno w swoich czynach i wszelkich ich skutkach, jak i w różnych mimowolnych dynamizmach, taka jest bowiem jego wewnętrzna struktura ${ }^{4}$. Obejmuje ona zarówno to, co jest

\footnotetext{
${ }^{2}$ Niewątpliwie istnieją jeszcze inne dynamizmy, którym (przynajmniej częściowo biernie) człowiek podlega, np. pojawiające się uczucia.

${ }^{3}$ Zauważmy, że skutek jako taki ma charakter pozamoralny, tym niemniej wydaje się, że niektóre $\mathrm{z}$ nich są moralnie doniosłe.

${ }^{4}$ Obok podmiotowości leżącej u podstaw uczynnień i podmiotowości leżącej u źródeł działa-
} 
dziełem decyzji, woli, jak i to, co leży poza jego kontrolą, a ma związek $\mathrm{z}$ reakcjami jego ciała. Człowiek jest istotą złożoną $\mathrm{i} w$ jego konstytucję wchodzi także ciało. Obecność ciała w ludzkim podmiocie sprawia, że nasze działania, uczynnienia oraz mimowolne reakcje są przez nie uwarunkowane i współkonstytuowane w całym ich przebiegu. Dlatego podmiot nie może zupełnie abstrahować od reakcji swojego ciała, nawet jeśli nie są one przez niego kontrolowane. Podmiot działania to nie tylko wola, ale całość wolitywno-cielesna 5 .

Poprzez swoją cielesność człowiek należy do świata fizycznego. Ludzkie ciało współkonstytuuje osobę ludzką i zarazem jest jednym $z$ istniejących fizycznych przedmiotów, a pozostając z nimi w bliższych i dalszych związkach, jest uczestnikiem zdarzeń i procesów zachodzących w tym świecie. Dzięki obecności ciała działanie podmiotu wraz ze skutkami staje się częścią fizycznego świata. Dlatego też istnieje znacząca różnica między samą decyzją woli a spełnionym działaniem. Decyzja ma charakter wewnętrzny, działanie zaś zewnętrzny. Co prawda działanie ma swój początek w decyzji, ale spełniane jest w świecie i dlatego pozostaje otwarte na wpływ okoliczności zewnętrznych ${ }^{6}$.

Podmiotu nie można więc zredukować wyłącznie do decyzji, do bycia źródłem aktów woli. Koncepcję podmiotu ujętego jako centrum decyzyjne można nazwać koncepcją „podmiotu czystego”. Przykładem takiego rozumienia podmiotu jest ,ja” noumenalne Kanta. Dla filozofa z Królewca ,ja” w swoim najgłębszym wymiarze jest niezdeterminowane, wolne od tego, co „światowe”, dzięki temu odporne na przygodność i związaną z tym zmienność (KANT 1957, 283-285)7. Zdaniem Margaret Walker noumenalne „ja”

nia Wojtyła wyróżnia także podmiotowość bardziej podstawową, leżącą u podstaw zarówno jednego, jak i drugiego dynamizmu. Ten podmiot „,podstawowy” Wojtyła nazywa suppositum. Niepodobna zaprzeczyć — pisze — że „ten, kto działa, jest równocześnie tym, w którym to i owo się dzieje”. WoJTYŁa 1994, 121-122. Podmiot-suppositum jest gwarantem jedności i tożsamości człowieka zarówno w dzianiu się, jak i w działaniu. Odnosząc powyższe odróżnienia do analizowanej przez nas sytuacji, trzeba stwierdzić, że tak jak jeden i ten sam podmiot leży u źródeł uczynnień wespół z działaniem, tak jeden i ten sam podmiot leży u podstaw zarówno działania, jak i wywołanych przezeń skutków, także przypadkowych.

${ }^{5}$ Jeden z rozdziałów swej książki Świadomość i pamięć. Uzasadnienie dualizmu antropologicznego Stanisław Judycki zatytułował znamiennie: „Wola i ucieleśnienie”. Stanisław JUDYCKI, Świadomość i pamięć. Uzasadnienie dualizmu antropologicznego (= JUDYCKI 2004, 332).

${ }^{6}$ Paul Ricoeur pisze, że ciało ,przez swe podwójne uzależnienie od porządku fizycznych ciał i od porządku osób znajduje się w punkcie styku między mocą działania, która jest naszą własną moca, a biegiem rzeczy, który należy do porządku świata”. (RICOEUR 2003, 185).

${ }^{7}$ Zdaje sobie sprawę, że jest to pewne uproszczenie i niewątpliwie istnieje relacja ,ja”-noumenalnego do ,ja”-empirycznego, nie zmienia to jednak faktu, że Kant bronił autonomiczności woli, wiążąc ją z rozumem, który racje znajduje wyłącznie w sobie samym, a nie w „fenomenalnym" świecie. 
u Kanta odpowiedzialne jest tylko za czyny woli, będące poza czasem i przestrzenią (W ALKER 1991, 244). Zarzut ten nie oznacza odmawiania woli dążenia do realizacji decyzji środkami, które są dostępne w tym świecie. Tym niemniej w sposób podstawowy moralność dotyczy aktów woli. Podobnie Husserlowskie ,ja” transcendentalne (,czyste «ja»”) jest całkowicie autonomiczne w stosunku do świata, jest właśnie „czystym podmiotem”8.

Zauważmy, że konsekwencją potraktowania podmiotu działania jako „czystego podmiotu" jest unieważnienie racji, aby poczuwać się do odpowiedzialności za drobne, nieumyślne zranienia, krzywdy czy nawet przypadkowe spowodowanie śmierci. „Podmiot czysty” nie musi przejmować się takimi zdarzeniami, nie są one bowiem czynami woli (WALKer 1991, 245). Gdyby kierowca był „czystym podmiotem”, nie musiałby się przejmować tym, że jest sprawcą wypadku. Nie poczuwałby się do obowiązku usprawiedliwiania się przed innymi za spowodowania niezamierzonego zła, nie widziałby racji próby rekompensaty czy innej formy pomocy.

Dla ukazania różnicy między „podmiotem czystym” a „nieczystym” odwołajmy się do przykładu podanego przez Walker. Kobieta pragnie mieć dziecko, ale jej intencja nie obejmuje urodzenia chorego dziecka. Tymczasem sam fakt bycia matką nakłada na nią zobowiązania, które pozostają niezależne od stanu zdrowia dziecka. Nawet gdyby dziecko urodziło się chore (co nie było objęte zamiarem kobiety), uznajemy, że kobieta powinna się nim zaopiekować ${ }^{9}$. Taka sytuacja, w której pewne skutki działań podmiotu (urodzenie dziecka) są ode niego niezależne (choroba dziecka), nakładają na niego odpowiedzialność, która nie miałaby racji w świecie czystych podmiotów (WALKER 1991, 245).

\footnotetext{
${ }^{8}$ Edmund Husserl pisze: „Na drodze fenomenologicznej epoche redukuję moje stanowiące część przyrody Ja i moje życie psychiczne - obszar mojego psychologicznego samodoświadczenia - do mojego Ja transcendentalno-fenomenologicznego, do obszaru trans cendentalno-fenomenologicznego samodoświadczenia". (HusserL 1982, 37). Efektem epoche jest „czyste «ja»” wraz z przynależną mu „czystą świadomością”. Podobne stanowisko, choć jako reprezentant etyki tomistycznej, zdaje się przyjmować Mieczysław Albert Krąpiec. W jego etyce moralna kwalifikacja przysługuje wyłącznie decyzji. Krąpiec pisze: „To wszystko [zewnętrzne, fizyczne wykonanie decyzji - uzup. moje A. K.] nie zmienia jednak charakteru aktu moralnego, który jest cały dany już w akcie decyzyjnym [...] Zatem zewnętrzne wykonanie ma doniosłe znaczenie i dla działającego człowieka, i dla realnego układu rzeczy, ale nie zmienia charakteru moralnego czynu ludzkiego, ukonstytuowanego przez ludzką decyzję". (KRĄPIEC 1983, 64). Jeżeli ,zewnętrzne wykonanie ma doniosłe znaczenie i dla działającego człowieka, i dla realnego układu rzeczy", to czy nie wnosi ono zatem nowego wymiaru moralnego do oceny działania? Inną sprawą jest, na czym polegałby ten nowy, moralny wymiar.

${ }^{9}$ Zdaję sobie sprawę, że istnieją różne sposoby uzasadnienia moralnych zobowiązań matki wobec dziecka np. fakt bycia przyczyną jego zaistnienia, czy nawiązana relacja matka-dziecko itd. Niewątpliwie jakieś zobowiązania kobieta posiada wobec urodzonego przez nią dziecka.
} 
Koncepcja „podmiotu czystego” przeczy jednak naszemu doświadczeniu. Ludzie nie funkcjonują przecież jako czyste podmioty woli, ale jako realni osobnicy psycho-fizyczni. W związku z tym nasza ludzka kondycja moralna jest znacznie bardziej skomplikowana. Jako istoty cielesne jesteśmy poniekąd zmuszeni zaakceptować nowe zobowiązania moralne, wynikające z nieprzewidzianych okoliczności. Okoliczności te stawiają przed nami moralne wyzwania, którym musimy sprostać. Przyczynienie się do śmierci dziecka stawia przed kierowcą konieczność jakiegoś ustosunkowania się do spowodowanej straty. Dlatego Bernard Williams powie, że idea dobrowolności jest w sposób istotny powierzchowna (WiLliams 1991, 253), gdyż nie ujmuje naszego faktycznego funkcjonowania w świecie. Jesteśmy odpowiedzialni nie tylko za działania w pełni kontrolowane. Także przypadkowe sploty wydarzeń w których uczestniczymy, wymagają zajęcia jakiejś moralnej postawy. Na przykład kiedy spaceruję brzegiem morza i zauważę tonącego człowieka, powinienem zareagować. Człowiek często staje wobec nieprzewidzianych sytuacji, które nakładają nań moralne zobowiązania.

Koncepcja która odzwierciedla nasze moralne uwikłanie w nieprzewidziane i niekontrolowane sytuacje, to koncepcja „podmiotu nieczystego"10, czyli takiego, którego podmiotowość nie redukuje się do samej woli. Działający podmiot to nie tylko dobrowolny sprawca, ale także ktoś, kto przez swą cielesność jest uwikłany w sytuacje i zdarzenia rozgrywające się w świecie. Podmiotem czynów moralnych nie jest „czyste «ja»”, ale osoba jako całość psychofizyczna, realny osobnik ${ }^{11}$. Występowanie skutków przypadkowych świadczy o uwikłaniu osoby i jej działania w świat. Sam sposób bytowania człowieka sprawia, że jego podmiotowość podatna jest na wpływ nieprzewidzianych zdarzeń. Zdarzenia te współokreślają zakres odpowiedzialności podmiotu ${ }^{12}$.

Nawet $\mathrm{w}$ moralności nie da się więc uciec przed tym, co przygodne (Williams 1991, 257). Przygodność moralna polegałaby na „wystawieniu”

\footnotetext{
${ }^{10}$ Cf. tytuł cytowanego już artykułu Margaret U. Walker „Moral Luck and the Virtues of Impure Agency”. Problem, w jaki sposób koncepcja „nieczystego podmiotu” wiąże się z kategorią trafu moralnego, jest tematem nader interesującym i wymaga osobnej rozprawy.

${ }^{11}$ Roman Ingarden pisze: „Zrealizowanie samego czynu jest podwójnie uwarunkowane: przez realne okoliczności, w których się on rozgrywa, i ewentualnie przez równie realne przyczyny w świecie, lecz z drugiej strony przez działającą i w momencie czynu rozwiniętą naturę osoby, przy czym naturalnie także jej ciało nie pozostaje bez wpływu na przebieg czynu". (INGARDEN 1973, 131.

${ }^{12}$ Jacek Filek twierdzi, że „człowiek znajduje się w stosunku odpowiedzialności nie dopiero jako sprawca określonego czynu, lecz jako człowiek; rozstrzygający jest tu nie charakter dokonanego przezeń czynu czy jego zaniechania, lecz samo usytuowanie człowieka w bycie". (FILEK 2003, 18 .
} 
działania i jego sprawcy na wpływ czynników przypadkowych, nieprzewidzianych. Refleksja nad problemem przyczynowania skutków niedobrowolnych i koniecznością zajęcia wobec nich postawy moralnej prowadzi nie tylko do uznania przygodności moralnej podmiotu, ale także swoistej paradoksalności. Paradoksalność ta polega na tym, że z jednej strony, $\mathrm{z}$ doświadczenia wewnętrznego czerpiemy ideę działającego „,ja” jako osobysprawcy i działania jako przejawu jej wolności, natomiast z drugiej, w perspektywie zewnętrznej to samo ,ja" staje się częścią świata a jego działanie poprzez skutki „przechodzi” w zdarzenie. Paradoksalność działającego ,ja” zdaje się wynikać z paradoksalności samego bytu ludzkiego. Polski epistemolog Antoni Stępień pisze:

Jeżeli paradoksem nazwiemy to, co dziwne, niezwykłe, trudne do zrozumienia i wyjaśnienia, to niewątpliwie człowiek stanowi szczególnie paradoksalny wypadek bytowy. Jest on ścisłą w życiu i działaniu jednością składników i czynników różnorodnych, wobec siebie pod wieloma względami opozycyjnych, jeśli nie wręcz antagonistycznych.(STĘPIEŃ 2001, 21-22).

Paradoksalność działania ma więc swoje źródło w paradoksalności bytowej człowieka. W człowieku i jego działaniu krzyżuje się bowiem to, co transcendentne wobec świata (intelektualno-wolitywne wnętrze), i to, co wobec świata immanentne (zewnętrzne ciało). Mamy z jednej strony, dzięki swojej autonomiczności, poczucie transcendencji wobec świata, ale z drugiej, przede wszystkim dzięki swojej cielesności, poczucie immanencji w tym świecie, bycia częścią świata.

\section{TożSAMOŚĆ PODMIOTOWA}

W zakres „podmiotowości nieczystej” wchodzi nie tylko działanie, ale także to, co nie jest zamierzonym skutkiem, a co pozostaje w związku z działaniem podmiotu. Kierowca ma świadomość, że to on spowodował wszystkie skutki, także te przypadkowe. Świadomość ta konstytuuje jego rozumienie swojej podmiotowości. „Podmiot nieczysty” jest zatem podmiotem „otwartym”. Jego podmiotowość w działaniu „rozpościera się” od własnych decyzji do wszystkiego tego, co z tym działaniem się wiąże, a zatem także przypadkowych skutków. Tak rozumiana podmiotowość utożsamia się z tym, co podmiot określa jako „moje”. „Moje” nie jest tylko wynikiem mojego zamierzenia, ale także obejmuje to, z czym czuję jakąś więź. Kierowca wie, że 
skutki przypadkowe są ,jego" i przynależą tym samym do jego podmiotowości ${ }^{13}$.

Uznanie „podmiotowości nieczystej” umożliwia ludziom zachowanie tożsamości podmiotowej. Nasza tożsamość moralna to nie tylko sprawstwo zamierzonych skutków, ale także świadomość bycia przyczyną różnych zmian w świecie. Skutki działań wpływają na inne osoby, ale zmieniają także sam podmiot, stając się częścią jego historii (Wolf 2001, 9). Dlatego dla zachowania integralności „całego” podmiotu nie wolno pomijać skutków przypadkowych, ściśle związanych z jego aktywnością (WiLliams 1999b, 226) ${ }^{14}$. Bez podjętego działania skutki przypadkowe nie zaistniałyby. Między działaniem a skutkami przypadkowymi zachodzi zatem dynamiczna relacja zależności i podmiot ma jej świadomość.

Zdaniem Bernarda Williamsa nie sposób ,zachować naszą tożsamość i charakter jako sprawcze podmioty" bez uwzględnienia naszego związku z zaistniałą sytuacją, nawet jeśli nie jesteśmy wprost za nią moralnie odpowiedzialni. W naszej praktyce moralnej, wiążemy podmioty ze spowodowanymi przez nich skutkami. Jeśli wiemy, że mają one charakter przypadkowy, wtedy nikt nie obarcza nas winą za zaistniałą sytuację. Mimo że podmiot jest niedobrowolnym sprawcą złych skutków, nie może się od nich zupełnie zdystansować, tak jak czyni to przypadkowy obserwator, niezaangażowany świadek. Inna jest bowiem pozycja kierowcy, a inna świadka wypadku. Kierowca dostrzega związek, ,jaki łączy go z nieprzemyślanymi aspektami jego działań, a także z ich aspektami nieprzewidzianymi i niezamierzonymi" (Williams 1999a, 212). Mimo że jest on mimowolnym sprawcą wypadku, włącza go w zakres swojej podmiotowości. Kierowca powie: „To ja przyczyniłem się do wypadku iw ten sposób wypadek stał się «moim»wypadkiem". Kierowca ma świadomość, że jest przyczyną zaistniałej sytuacji i świadomość ta jest podstawą zachowania moralnej tożsamości. Uznanie przez podmiot integralnego związku między działaniem a przypadkowymi

\footnotetext{
${ }^{13}$ Zachodzi podobieństwo między włączeniem skutków przypadkowych w zakres podmiotowości a tym, co Józef Tischner nazywa egotyczna solidaryzacją. „Przez solidaryzację egotyczną rozumiem zjawisko utożsamiania się ja z obszarem, który pierwotnie był bądź tylko obszarem «mojego», bądź stanowił teren całkowicie aegotyczny, w rezultacie czego obszar ten nabiera znaczenia bycia integralnym składnikiem konstytucyjnym obszaru ścisłej egotyczności (ja będącego fundamentem solidaryzacji)”. (TISCHNER 1971, 69). Zauważmy, że istotnym rysem relacji „,ja”„moje” jest stopniowalność „,mojego”. Coś może być w różnym stopniu „moje”, a zależy to od tego, czy podmiot włączy to w zakres swojej podmiotowości (w języku Tischnera - egotyczności).

${ }^{14}$ Zdaniem Williamsa nasza podmiotowa tożsamość obejmuje zarówno dobrowolne, jak i niedobrowolne aspekty naszych działań. Pominięcie tych drugich w rozumieniu tożsamości sprawia, że tracimy tym samym charakter sprawcy działania.
} 
skutkami ujawnia, że za nasza podmiotowość w działaniu nie ogranicza się do dobrowolności.

Trzeba podkreślić, że powyższe stwierdzenia nie podważają różnicy między intencjonalnym a nieintencjonalnym przyczynowaniem skutków. Fundamentalne doświadczenie sprawczości intencjonalnej (dobrowolnej) leży u podstaw naszego rozumienia odpowiedzialności moralnej. Trudno nie zgodzić się ze stwierdzeniem, że dla zachowania zdolności funkcjonowania jako intencjonalni sprawcy działania musimy uznać, że oceniamy moralnie podmiot $\mathrm{w}$ zależności od jego intencji, a nie przypadkowo powodowanych rezultatów (JENSEN 1991, 136 i 139). Właściwa autonomicznemu podmiotowi sprawczość to jednak jedna odsłona naszej podmiotowości, pozostaje jednak i druga, związana z posiadanym ciałem i jego uwikłaniem w splot zdarzeń. Tak jak dobrowolność działań i świadomość rozdźwięku między zamierzeniem i przypadkowym powodowaniem skutków umożliwia nam zachowanie różnicy między sprawczością intencjonalną a przyczynową, tak i tożsamości podmiotowej (decyzyjno-cielesnej — jeśli tak można powiedzieć) nie da się zachować bez uznania związku naszych działań ze spowodowanymi skutkami, w tym skutkami przypadkowymi. Dla zachowania podmiotowej tożsamości istotne są obydwie odsłony podmiotowania: bycie ośrodkiem decyzyjnym (dobrowolnym) oraz bycie przyczyną zaistnienia różnych stanów rzeczy.

\section{D. ŻAL SPRAWCY A SPOWODOWANA STRATA}

Uznanie związku podmiotu ze spowodowaną stratą znajduje wyraz w przeżyciu żalu. Żal, jaki odczuwa sprawca wypadku, nie jest tylko emocjonalną rekcją, ale wyrazem świadomości swojej roli w zaistniałej sytuacji. Niewątpliwie sam fenomen żalu jest uczuciem złożonym, dlatego trzeba wskazać na to, co charakterystyczne dla żalu doświadczanego przez nieumyślnego sprawcę wypadku.

Elementem konstytutywnym każdego żalu jest myśl: „o ile lepiej by było, gdyby było inaczej" (Williams 1999b, 223). Tym, czego w ogólnym sensie się żałuje, są stany rzeczy i może ich żałować każdy, kto zdaje sobie z nich sprawę. Dlatego żal może przeżywać nie tylko sprawca, ale i świadek zdarzenia. Świadek żałuje, że dana sytuacja miała miejsce, że stało się coś, co przyniosło komuś krzywdę. Żal mu, współczuje ofierze wypadku. Sprawca wypadku żałuje zaś, że w ten, a nie inny sposób przyczynił się do zaist- 
niałego stanu rzeczy ${ }^{15}$. Typowy przykład żalu sprawcy mamy wtedy, gdy podmiot można obarczyć winną za zaistniałą sytuację. Tak byłoby wtedy, modyfikując nasz przykład kierowcy, gdyby kierowca np. nie sprawdził stanu hamulców przed jazdą, a miał taki obowiązek. I w tym przypadku kierowca broniłby się, że śmierć dziecka nie była przez niego zamierzona, uznamy jednak, że swoim zaniechaniem stworzył możliwość pojawienia się negatywnych konsekwencji. W takiej sytuacji żal kierowcy jest jak najbardziej uzasadniony i wyraża się nie tylko w pragnieniu, aby dana sytuacja w ogóle nie zaistniała, ale też $\mathrm{w}$ pragnieniu, aby on sam zadziałał inaczej - zrobił przegląd samochodu przed wyruszeniem na drogę.

Czy żal odczuwany przez kierowcę z naszego przykładu, któremu nie możemy nic zarzucić, a który jednak stał się niedobrowolnym sprawcą wypadku, ma charakter zbliżony do żalu świadka czy żalu sprawcy? Jak zaznacza Bernard Williams, „odczucie żalu sprawcy z żadnym razie nie ogranicza się do działań dobrowolnych. Może ono wybiegać daleko poza to, co człowiek uczynił rozmyślnie, i wiązać się nieledwie z czymkolwiek, za co jest on przyczynowo odpowiedzialny na mocy jakiegoś rozmyślnego działania" (Williams 1999b, 224). Kierowca rozważny podziela myślenie kierowcy lekkomyślnego, on także chciałby postąpić inaczej, np. wybrać inną drogę albo wyruszyć o innej godzinie. Ma on świadomość, że nie był tylko biernym obserwatorem danego zdarzenia, ale miał wpływ na jego przebieg. Kierowca czuje się sprawcą wypadku, zna i rozumie związek swojego działania z zaistniałym skutkiem (GREENSPAN 1983, 151-152). Także zewnętrzni obserwatorzy mają świadomość, że rzeczywiście „w jego relacji do tego zdarzenia jest coś szczególnego, coś, czego nie da się po prostu przekreślić z tej racji, że nie popełnił on żadnego błędu" (WILliams 1999b, 224). Żal, który odczuwa kierowca, to żal sprawcy, a nie świadka. Kierowca ma świadomość swojego związku z wypadkiem, świadomość nieodwracalnej, doniosłej rangi straty. Przekonanie kierowcy ma zaś swoją podstawę w obiektywnej rzeczywistości, w zaistniałych faktach. Żal sprawcy, nawet sprawcy mimowolnego, potwierdza nierozerwalność podmiotu i skutków jego działania.

\footnotetext{
${ }^{15}$ Są różne rodzaje żali i na co innego wskazują. Żal kierowcy nie jest oczywiście dowodem jego moralnej winy. Jest to żal z powodu spowodowania wypadku. Spowodowanie wypadku stanowi kognitywną podstawę żalu. Ton uczuciowy żalu może być podobny u sprawcy, jak i u świadka. Ale inna jest podstawa poznawcza żalu obserwatora, inna zaś kierowcy.
} 


\section{STRUKTURA DZIAŁANIA A SKUTKI PRZYPADKOWE}

Jak już powiedzieliśmy, działania nie można sprowadzić tylko do decyzji, by działać. Możemy powiedzieć, że jest ono czymś częściowo zamkniętym, ze względu na wewnętrzny charakter intencji i decyzji woli podmiotu, częściowo zaś otwartym - poprzez kontakt ze zmiennymi okolicznościami, krótko mówiąc: ze względu na interakcje z otoczeniem, z kontekstem w którym jest spełniane. To, co w działaniu zamknięte, jest dziełem decyzji podmiotu $^{16}$, to zaś, co w działaniu otwarte, to wyraz jego podatności na wpływ rzeczywistości, działań innych osób, niezależnych od niego okoliczności itd. Dlatego, posługując się terminologią Ingardena, stosowaną co prawda do opisu podmiotu, można powiedzieć, że działanie jest pewnym systemem względnie izolowanym (INGARDEN 1973, 134-136) ${ }^{17}$. Tylko „względnie izolowanym”, albowiem poprzez swoją nieuchronną interakcję ze światem, działanie pozostaje otwarte na różne wpływy i zdarzenia. Stąd jego całkowite treściowe określenie nie jest całkowicie dane w momencie decyzji. Podejmując decyzję i działanie, przewiduję, jakie skutki może ono przynieść. Nie wszystkie skutki są jednak możliwe do przewidzenia. Skutki przypadkowe wskazują na otwartość działania, na to, co nie podlega kontroli podmiotu, a jednak ma istotny wpływ na ostateczny charakter samego działania. Otwartość działania na wywoływanie różnych skutków wskazuje, że skutki $\mathrm{w}$ istotny sposób je dookreślają. To skutki wraz z działaniem tworzą jego integralną całość.

Ze względu na związek działania i jego skutków nie możemy więc traktować działania jako czegoś w pełni określonego, „zamkniętego”. Nie oznacza to, że dane działanie przestaje być czymś w sobie identyfikowal-

\footnotetext{
${ }^{16}$ Fakt, w jaki sposób decyzja jest podejmowana, wpływ czynników niezależnych od podmiotu na kształt decyzji, koncepcja namysłu i jego relacji do działania - te wszystkie tematy nie są istotne dla mojej analizy.

${ }^{17}$ Ingardena koncepcja systemu względnie izolowanego różni się od koncepcji takiego systemu w biologii. Ingarden nadał temu systemowi interpretację ontologiczną (INGARDEN 1973, 138) i taka właśnie interpretacja pozostaje dla mnie wiążąca. Warto podkreślić, że otwartość działania, związana z samą specyfiką tego aktu, ma inny charakter niż „otwartość” podmiotu, który zachowuje swoją autonomię pomimo różnych wpływów. „Aby w swojej decyzji i swoim wypływającym z niej działaniu być «niezależną» od otoczenia, osoba musi przede wszystkim mieć w sobie centrum działania, które umożliwia jej uchwycenie inicjatywy, a zarazem mieć w swej budowie urządzenia obronne, aby nie przeszkadzano jej w działaniu. Musi być jednak podatna na ingerencje pochodzące z zewnątrz o tyle, że jej odpowiedzialność płynie z określonej postaci jej wpółżycia $\mathrm{z}$ otaczającej ją rzeczywistością, a w szczególności z innymi ludźmi. W swoich właściwościach i postępowaniu musi tedy być «otwarta» i podatna, a zarazem pod innym względem chroniona i niewrażliwa”. (INGARDEN 1973, 133).
} 
nym, a tym samym zrozumiałym. Fakt dookreślania działania przez skutki nie podważa jego inteligibilności. Możemy zgodzić się, że działanie jest czymś, że ma swoją naturę, przez którą zmierza do określonego celu. Nie oznacza to jednak, że jako takie stanowi zamkniętą, całkowicie określoną jednostkę. Otwartość działania na dookreślenie przez skutki powoduje, że nieprzekonująca jest koncepcja Roberta Spaemanna, uznającego działanie za całkowicie zamkniętą jednostkę sensu. Zdaniem Speamanna czyny można potraktować jako zdania, które charakteryzują się swoją określonością. „Jeśli czyny ludzkie są rodzajem języka, tj. jeśli mają w ogóle być postrzegane jako akty ludzkie, to muszą posiadać jakiś rodzaj natury ogólnej, która może stać się przedmiotem oceny" (SPaEmann 1996, 39). Każdy czyn, posiadając naturę ogólną może zostać zakwalifikowany do określonego rodzaju. Sama natura czynu, jak twierdzi Spaemann, ujawniająca się w momencie decyzji pozostaje niezmienna bez względu na to, co czyn ostatecznie spowoduje. Trzeba jednak zaznaczyć, że czyn konkretyzuje się w określonym kontekście. Natura czynu, będąc ogólna, nie uwzględnia istotnych okoliczności, które dookreślają charakter działania. Ogólna natura czynu w konkretnych okolicznościach przybiera określoną formę i domaga się właściwej odpowiedzi podmiotu. Podejmowane działanie jest więc otwarte na możliwość pojawienia się m.in. skutków przypadkowych, a one z kolei dookreślają, z jakim typem działania mieliśmy do czynienia. Adekwatna ocena takiego działania jest możliwa dopiero po ujawnieniu się skutków, albowiem - jak stwierdza Williams - dopiero po fakcie ujawnia się, czym ono ostatecznie było (WiLLIAMs 1999b, 233).

Jeżeli działanie ujawnia swoją naturę dopiero z czasem, w zależności od konsekwencji, do jakich prowadzi, adekwatna deskrypcja działania możliwa jest dopiero post factum. Niektóre skutki działania zależą zaś od tego, nad czym człowiek nie miał kontroli. To nieprzewidziane okoliczności sprawiają, że dane skutki zaistnieją albo nie. Skutki, także te przypadkowe, konstytuują to, czym działanie rzeczywiście było, a nie tylko należą do jego okoliczności ${ }^{18}$. Przywołajmy przykład podany przez Thomasa Nagela. To, w jaki

\footnotetext{
${ }^{18}$ Dlatego nie sposób zgodzić się z etyką tomistyczną, która skutki działania zaliczała do okoliczności. Zob. np. WORONIECKI 1986, 265. Jacek Woroniecki tak pisze: „O k ol i c z n ośc i a mi moralnymi nazywamy te przypadłości zewnętrzne lub wewnętrzne naszych czynów, które i pod względem moralnym mają jakieś znaczenie. [...] Okoliczności te mogą dotyczyć albo samego czynu albo jego przyczyn, albo wreszcie skutków, czyli rezultatów”. Zob. także JuRos i STYCZEŃ 1973, 266. Czytamy tam, że okoliczności „to inne elementy modyfikujące [moralną kwalifikację czynu - uzup. A.K.], jak osoba działająca (kto), skutek działania (co), sposób działania (jak) itp.”.
} 
sposób oceniamy działania dekabrystów z 1825 r., uzależnione jest zdaniem Nagela - od tego, czy osiągnęli swój cel. Dekabryści wiedzieli, że ryzykują, przewidywali możliwość niepowodzenia swojej akcji. Nie tylko wiedza i intencja określają działanie, ale także „obrót, jaki sprawy przybiorą, zadecyduje o tym, co (ktoś) uczynił" (NAGEL 1997, 43). Gdyby dekabrystom udało się obalić cara Mikołaja I, byliby bohaterami, ale się im nie udało i musieli za to srogo zapłacić. W zależności od skutków czyn dekabrystów był bohaterski albo lekkomyślny (ibid., 40).

O przynależności więc działania do danej kategorii mogą zadecydować pojawiające się skutki. Stróż nocny, który opuszcza swoje stanowisko, aby pomóc dziecku napadniętemu przez dwóch wyrostków, dokonuje czynu bohaterskiego, ale jeśli w tym czasie bank zostanie obrabowany, powiemy, że nie dopatrzył swoich obowiązków i jest nieodpowiedzialnym pracownikiem (RESCHER 1991, 153). To, czym ostatecznie okaże się dane działanie i w jaki sposób je ocenimy, zależy nie tylko od tego, co było zamiarem podmiotu, ale także od tego, co ono spowodowało. Nie tylko skutki, ale i okoliczności działania ujawniają, czym było dane działanie. Złodziej, który okrada swojego dziadka w momencie, kiedy tamten zmarł i przepisał mu całe mienie, nie jest już złodziejem — zgarnia swoją własność. To nie oznacza, że ocena tego działania jako kradzieży jest bezpodstawna. Ale z perspektywy zewnętrznego obserwatora, posiadającego odpowiednią wiedzę, nie jest to już czyn złodziejski (ibid., 152) ${ }^{19}$.

Nie bez znaczenia dla określenia, czym jest dane działanie, jest jego relacja do wcześniejszych działań podmiotu. Jedne działania są poprzedzone innymi. Nietrudno zgodzić się ze zdaniem Alasdaira MacIntyre’a, że „każdy czyn jest epizodem w jakiejś możliwej historii" (MACInTyre 1996, 386), czyli jest częścią łańcucha działań. Działania na siebie zachodzą i wzajemnie się warunkują. W analizowanym przykładzie kierowcy skutki działania mogłyby nie być jedynie wypadkową niekorzystnych okoliczności i przypadkowego udziału dziecka w zdarzeniu. Uprzednie wobec wypadku działanie, np. zaniedbanie sprawdzenia sprawności hamulców, mogło mieć istotny wpływ na ostateczny skutek. Kierowca nie zamierzał śmierci dziecka, ale może poprzez swoje zaniedbanie ją spowodował. Możemy wyobrazić sobie jednak, że nawet jeśli zaniedbanie miało miejsce, to nie miało ono wpływu na wynik działania. Nawet gdyby hamulce działały sprawnie, kierowca

\footnotetext{
${ }^{19}$ Oczywiście odpowiedzialność podmiotu za działanie zrelatywizowana jest do jego wiedzy. Złodziej odpowiada za kradzież, taka była bowiem jego intencja. Złodziej pozostaje wewnętrznie złodziejem. Nie zmienia to faktu, że działanie nie było ostatecznie przypadkiem kradzieży.
} 
zabiłby dziecko, nie zdążyłby bowiem wyhamować. Zaniedbanie mogłoby więc nie mieć wpływu na to, co się wydarzyło. Choć działanie znajduje się zawsze w ciągu działań, to jednak nie tak łatwo stwierdzić związek między wcześniejszymi a obecnymi działaniami oraz ich skutkami. Taki związek nie zawsze jest oczywisty, trudno niekiedy wskazać, które skutki były przedmiotem zamierzenia albo przewidywania, a które były przypadkowe. Szczególnie w sytuacji spowodowania znaczącej straty, a taką niewątpliwie jest śmierć dziecka, doszukujemy się związku z uprzednimi zaniedbaniami i działaniami. Podejrzewamy, że działanie mogło mieć znamiona niedopatrzenia, lekkomyślności. Trudno jednak w sposób jasny wytyczyć — jak już mówiliśmy - granicę między tym, nad czym podmiot miał kontrolę, a tym, nad czym już jej nie miał.

Integralny związek skutków z działaniem sprawia, że mają one wymiar moralny. Gdyby w moralności liczyły się tylko intencje, to rzeczywiście można by powiedzieć, że nie ma adekwatnego uzasadnienia, aby karać zrealizowane działania surowiej niż same nieudane próby. Okazuje się jednak, że przy ocenie moralnej działania aktualne skutki są dla nas równie istotne co zamiar. Nagel pisze, że ,jakkolwiek by nieskazitelnie dobra była wola sama w sobie, istnieje moralnie znacząca różnica między wyratowaniem kogoś $\mathrm{z}$ płonącego budynku a zrzuceniem go $\mathrm{z}$ okna $\mathrm{z}$ dwunastego piętra przy próbie ratowania" (NAGEL 1997, 38). W przykładzie kierowcy spowodowana strata-śmierć dziecka nabiera rangi moralnej i nie pozostaje bez znaczenia $\mathrm{W}$ ocenie samego działania. Dlatego ze spowodowanego zła musimy się wytłumaczyć, a sama możliwość podania racji bądź wskazanie na ich brak nie jest moralnie neutralna. Nie oznacza to, że wymóg wytłumaczenia się przed inną osobę ze swojego działania przesądza o winie i moralnej odpowiedzialności. Konieczność podania usprawiedliwienia swoich działań jest jednak naszym obowiązkiem. Takie usprawiedliwienie ma na celu, z jednej strony, wykazanie braku naszej winy, z drugiej — wykazanie świadomości przyczynienia się do tragedii. Szczególnie winni jesteśmy usprawiedliwienia wobec tych którzy ponieśli straty w wyniku naszych działań. Kierowca jest świadom, że śmierć dziecka jest stratą doniosłą, nieodwracalną $^{20}$. Wszelkie działania, których rezultatem jest śmierć (nawet jeśli niezamierzona) człowieka, domagają się więc usprawiedliwienia.

Zauważmy, że w naszej moralnej praktyce skutki niekiedy są istotniejsze niż intencje. Nie da się zaprzeczyć, że człowiek, który zabił, zrobił coś

\footnotetext{
${ }^{20}$ Przypomnijmy, że z perspektywy podmiotu działającego życie drugiego człowieka jest najwyższą wartością, wartością o fundamentalnej moralnej doniosłości.
} 
gorszego niż ten, który tylko próbował zabić. Fakt ten wskazuje, że skutki nie są czymś oddzielnym od działania i je także należy uwzględnić, oceniając działanie. Jeśli podstawowy, zamierzony skutek działania się nie pojawi, możemy mieć wątpliwości, z jakim typem działania mieliśmy do czynienia. Czym innym jest działanie-zabójstwo, a czym innym nieudana próba zabójstwa. W obu przypadkach sprawca zaciaga moralną winę, jego intencja była moralnie zła. Tym niemniej dla oceny samego działania, różnica $\mathrm{w}$ spowodowanych skutkach ma moralne znaczenie. Mamy więc moralne podstawy, aby działanie zabójcy ocenić surowiej niż samą próbę zabójstwa.

Otwarty i niezdeterminowany charakter działania, jego niejawne relacje do powodowanych skutków i poprzedzających je działań sprawia, że nawet te działania, które pozostają częściowo poza naszą kontrolą, roszczą sobie uzasadnione pretensje do uwzględnienia w moralnej ocenia działania.

\section{OBOWIĄZEK ODPOWIEDZIALNOŚCI ZA PRZYPADKOWE SKUTKI DZIAŁANIA}

Mówiąc o odpowiedzialności, najczęściej mamy na myśli działania i skutki, które należą do podstawowego zakresu ludzkiej sprawczości. Człowiek jest odpowiedzialny za swoje dobrowolne działania oraz zamierzone i przewidywane skutki. W tym momencie, gdy człowiek podejmuje decyzję i rozpoczyna działanie, staje się tym samym za nie odpowiedzialny. Odpowiedzialność taka nie jest aktem woli, po prostu jest konsekwencją naszych wyborów, jak podkreśla David Enoch $(2012,100)^{21}$. Niewątpliwie istnieją rzeczy wykraczające poza zakres ludzkiej sprawczości. Ruchy planet, działania innych ludzi, którzy nie stają w jakiejś relacji do podmiotu, znajdują się poza jego kontrolą. Człowiek, nawet jeśliby chciał, nie może wziąć odpowiedzialności za takie zdarzenia, nie leży to bowiem w jego mocy. Ale istnieją działania, które znajdują się — jak się wyraża Enoch - w półcieniu sprawczości ${ }^{22}$, i do takiego typu działania, jego zdaniem, należy

\footnotetext{
${ }^{21}$ Mówiąc, że odpowiedzialność staje się faktem, Enoch zdaje się mieć na myśli jej wyjście poza wewnętrzny zakres decyzji podmiotu.

${ }^{22}$ Kategoria półcienia sprawczości oznacza, tak zdaje się sugerować Enoch, że trudno niekiedy wyznaczyć ostrą granicę między właściwą sprawczością a tym, co jest jej „półcieniem”. Trzeba w związku z tym zauważyć, że nie jest to jedyny „półcień”w strukturze człowieka. Także trudno przeprowadzić ostrą granicę między tym, co cielesne, a tym, co psychiczne, między świadomością a cielesnością, między tym, co osobowe, a tym, co pozaosobowe. „Półcień” jest następstwem złożonej natury człowieka i brakiem ściśle określonej granicy między jej elementami. Ka-
} 
analizowany przypadek kierowcy. Podmiot nie jest odpowiedzialny za skutek jako za urzeczywistnienie swojego zamiaru, ale powinien w sposób odpowiedni (odpowiedzialny) ustosunkować się do zaistniałej sytuacji. Jego odpowiedzialność nie zależy tutaj od tego, co bezpośrednio leżało w zakresie właściwej sprawczości, ale poprzez akt woli może uczynić siebie odpowiedzialnym. Może bowiem wziąć odpowiedzialność za zaistniałą stratę. Podmiot staje się wtedy odpowiedzialny w wyniku swojego aktu woli. Nie jest to jednak wyłącznie kwestia arbitralnej decyzji podmiotu. Powaga sytuacji, w jakiej się znalazł, niejako przymusza go do tego. Williams powie nieco metaforycznie, że ,sprawiedliwość wymaga aby koszta tego zdarzenia zapisać na własne konto" (Williams 1999b, 225). Odpowiedzialność za nieszczęśliwy skutek jest więc $\mathrm{z}$ jednej strony spowodowana decyzją podmiotu, $\mathrm{z}$ drugiej zaś ma swoje ugruntowanie w specyficznej jego relacji do zaistniałej straty. Obowiązek wzięcia odpowiedzialności za przypadkowe skutki ma swoją podstawę $\mathrm{w}$ fakcie, że znajdowały się one $\mathrm{w}$ półcieniu sprawczości podmiotu. Dlatego odpowiednią i wymaganą reakcją nieszczęśliwego kierowcy na spowodowanie wypadku byłaby konstatacja: „to nie był wynik mojego umyślnego działania, nie mogę być za to odpowiedzialny. Tym niemniej ze względu na swój udział w zaistniałej sytuacji powinienem wziąć za nią odpowiedzialność”. Williams powie, że „bycie odpowiedzialnym nie sprowadza się jedynie do zasadnego przypisywania mu (podmiotowi) odpowiedzialności przez innych, [...] ale polega na uznaniu własnej odpowiedzialności” (Williams 1999a, 213) ${ }^{23}$. W tym sensie, zdaniem autora, „odpowiedzialność może wykraczać poza działania dobrowolne” (ibid.) ${ }^{24}$. Uznanie własnej odpowiedzialności nie jest tylko subiektywną decyzją podmiotu, ale w przypadku powodowania straty ma obiektywną podstawę. Owa obiektywna podstawa ma swoje źródło, z jednej strony, w integralnym związku skutków niedobrowolnych z działaniem (gdyby nie było działania, skutki by nie zaistniały), $\mathrm{z}$ drugiej zaś $\mathrm{w}$ randze powodowanej straty (w naszym przykładzie jest to śmierć dziecka).

Aby bliżej wyjaśnić charakter obowiązku wzięcia odpowiedzialności za przypadkowe skutki działania, odwołajmy się do sytuacji złożenia obietnicy.

tegoria półcienia sprawczości jest także wyrazem uznania, że nasza odpowiedzialność za to, co sprawiamy, jest stopniowalna, ponieważ stopniowalna jest zarówno świadomość jak i wolność, leżące u źródeł sprawczości.

${ }^{23}$ Ingarden określił to jako branie odpowiedzialności za coś. INGARDEN 1973, 78.

${ }^{24}$ Podobną myśl wyraża Jacek Filek, uznając, że człowiek jest „odpowiedzialny nie tylko za swój czyn i jego wynik, lecz przede wszystkim jest odpowiedzialny za to, co wydarza się w obszarze jego możliwego wpływu, a być może nawet i poza tym obszarem”. (FILEK 2003, 204). 
W przypadku obietnicy, jak stwierdza Enoch, podmiot jest odpowiedzialny za jej wypełnienie nie dlatego, że zaistniał jakiś uprzedni wobec obietnicy obowiązek działania. Człowiek sam, aktem swojej woli (aktem złożenia obietnicy), staje się za nią odpowiedzialny. Złożenie obietnicy nie jest związane $\mathrm{z}$ rozpoznaniem przez podmiot jakiegoś obowiązku, który istniał już uprzednio, niezależnie od obietnicy. Składając obietnicę, podmiot sam siebie wiąże obowiązkiem, stwarza obowiązek, który następnie winien jest spełnić (ENOCH 2012, 105). Podobnie obowiązek wzięcia odpowiedzialności za przypadkowe skutki związane jest z decyzją podmiotu.

Decyzja o przyjęciu odpowiedzialności nie jest jednak wyłącznie kwestią woli podmiotu. Podmiot powinien minione zdarzenie, skutki, które spowodował, włączyć w zakres swojego półcienia sprawczości. Nie oznacza to, że podmiot włącza je w sferę właściwej sprawczości, ale jedynie, że bierze za nie odpowiedzialność. Podmiot może być zobowiązany do przyjęcia odpowiedzialności, nawet jeśli działanie nie było stricte jego działaniem ${ }^{25}$. To, że wziął za coś odpowiedzialność, ujawnia się w jego kolejnych aktywnościach. Do takich działań zalicza się rekompensata, wytłumaczenie się z tego, co uczynił, przeprosiny poszkodowanego, wyrazy współczucia etc. To podmiot winny jest takie działania spełnić (i nie może obciążyć nim np. funduszu ubezpieczeniowego ${ }^{26}$ ). Enoch podkreśla, że branie odpowiedzialności ma często charakter explicite, ale wielokrotnie przyjmuje postać implicite i ujawnia się we wspomnianych wcześniej przeprosinach i rekompensacie (ibid., 116-117). Podmiot, który w sytuacji, gdy jego działanie spowodowało szkody, nie bierze odpowiedzialności, odsłania — zdaniem Enocha — swój brak woli spełniania obowiązku (ibid., 114).

Enoch zauważa, że obowiązek wzięcia odpowiedzialności ujawnia, że nasza podmiotowość i odpowiedzialność nie może zostać zamknięta w tym, co nazywamy jej rdzeniem (ibid., 100). Koncepcja Enocha wskazuje, że wzięcie odpowiedzialności za pojawienie się nieprzewidzianych skutków naszego działania nie obala naszego rozumienia odpowiedzialności moralnej, a jedynie domaga się uznania, że istnieje sfera półcienia naszej

\footnotetext{
${ }^{25}$ Słyszymy niekiedy, że jakiś przełożony wziął odpowiedzialność za działanie swego podwładnego czy podwładnych, mimo że nie był ich sprawcą. Nie traktujemy takiej deklaracji przełożonego jako absurdalnej. Widocznie uważamy takie postępowanie za racjonalnie uzasadnione. Można wziąć odpowiedzialność za coś, czego nie było się sprawcą.

${ }^{26}$ Fundusz ubezpieczeniowy wypłaca jedynie odszkodowanie w imieniu ubezpieczonego, ale nie jest zobowiązany do „osobowych” gestów, świadczących o wzięciu odpowiedzialności za to, co się stało. Wykupienie polisy ubezpieczeniowej nie sprawia, że unieważnia ona mój udział w spowodowanym wypadku.
} 
sprawczości. Stanowisko Enocha zawiera przekonanie, że podstawowa odpowiedzialność ma swe źródło w dobrowolności działania, a zarazem daje wyraz intuicji, że podmiot winien wziąć odpowiedzialność za niedobrowolne skutki swoich działań ${ }^{27}$. Wprowadzając koncepcję półcienia sprawczości, możemy zaadaptować fakt niedobrowolnych skutków do moralnej interpretacji ludzkiego działania w świecie.

Podsumowując, należy stwierdzić, że podmiot ma obowiązek wziąć odpowiedzialność za niedobrowolne skutki swoich działań, a ma to swoją podstawę $\mathrm{w}$ zespole wskazanych różnych racji: przede wszystkim w naturze (psychiczno-cielesnej) działającego podmiotu i jego podmiotowej tożsamości oraz w relacji przyczynowej, łączącej go z niedobrowolnymi skutkami. Ponadto racje te tkwią w braku wiedzy: o relacji łączącej dany skutek i dane działanie, o relacji działania do poprzednich działań, o stopniu kontroli nad zaistniałymi skutkami. Brak wiedzy co do związku danego działania z działaniami poprzedzającymi potwierdza istnienie obowiązku wzięcia odpowiedzialności za niedobrowolne skutki działań. Nie oznacza to, że w przypadku całkowicie pewnej wiedzy na ten temat obowiązek taki by się nie pojawił. Niewiedza nie jest więc warunkiem koniecznym pojawienia się obowiązku, jakkolwiek go wzmacnia. Wszystkie powyższe przesłanki potwierdzają zasadność obowiązku wzięcia odpowiedzialności za spowodowaną stratę.

\section{BIBLIOGRAFIA}

ENOCH, David. 2012. „Being Responsible, Taking Responsability, and Penumbral Agency”. W: Luck, Value, and Commitment, red. Ulrike Heuer i Gerald Lang, 95-132. Oxford: Oxford University Press.

FILEK, Jacek. 2003. Filozofia odpowiedzialności XX wieku. Kraków: Wydawnictwo ZNAK.

Greenspan, P[aricia] S. 1983. Practical Guilt. Moral Dilemmas, Emotion, and Social Norms. New York, Oxford: Oxford University Press.

HuSSERL, Edmund. 1982. Medytacje kartezjańskie. Przełożył Andrzej Wajs. Warszawa: Państwowe Wydawnictwo Naukowe.

INGARDEN, Roman. 1973. „O odpowiedzialności i jej podstawach ontycznych”. W: IDEM. Ksiażeczka o człowieku, 77-184. Kraków: Wydawnictwo Literackie.

Jensen, Henning. 1991. „Morality and Luck”. W: Moral Luck, red. Daniel Statman, 131-140. Albany: State University of New York Press.

JUDYCKI, Stanisław. 2004. Świadomość i pamięć. Uzasadnienie dualizmu antropologicznego. Lublin: Towarzystwo Naukowe KUL.

\footnotetext{
${ }^{27}$ Alasdair MacIntyre zdaje się reprezentować podobne stanowisko, kiedy pisze, że podmioty moralne „można pociagnać do odpowiedzialności za przypadkowe aspekty ich czynów, których winny być świadome”. (MACINTYRE 2009, 272).
} 
JuROS, Henryk, i Tadeusz STYCZEŃ. 1973. „Moralny akt ludzki”. W: Encyklopedia Katolicka. T. 1. Lublin: Towarzystwo Naukowe KUL.

KANT, Immanuel. 1957. Krytyka czystego rozumu. T. II. Przełożył Roman Ingarden. Kraków: Państwowe Wydawnictwo Naukowe.

KRĄPIEC, Mieczysław. 1983. „Decyzja — bytem moralnym”. Roczniki Filozoficzne 31, z. 2: 47-65.

MacIntyre, Alasdair. 1996. Dziedzictwo cnoty. Przełożył Adam Chmielewski. Warszawa: Państwowe Wydawnictwo Naukowe.

MACINTYRE, Alasdair. 2009. „Struktury społeczne i ich zagrożenia dla moralnej sprawczości”, przeł. Adam Chmielewski, w: IDEM, Etyka i polityka, red. naukowa Adam Chmielewski. Warszawa: Wydawnictwo Naukowe PWN.

NAGeL, Thomas. 1997. „Traf w życiu moralnym”. W: Idem. Pytania ostateczne. Przełożył Adam Romaniuk. Warszawa: Fundacja Aletheia.

RESCHER, Nicholas. 1991. „Moral luck”. W: Moral Luck, red. Daniel Statman, 141-166. Albany: State University of New York Press.

Ricoeur, Paul. 2003. O sobie samym jako innym. Przełożył Bogdan Chełstowski. Warszawa: Wydawnictwo Naukowe PWN.

SpaemanN, Robert. 1996. „Czyn a piękne życie. O pojęciu natury czynu”. Przełożył Jarosław Merecki. Ethos 9, nr 1-2 (33-34): 31-41.

STĘPIEŃ, Antoni B. 2001. „W poszukiwaniu istoty człowieka ( $\mathrm{Z}$ fenomenologii i metafizyki ludzkiego bytu)". W: IDEM. Studia i szkice filozoficzne. Część II. Lublin: Redakcja Wydawnictw KUL.

Tischner, Józef. 1971. Aksjologiczne podstawy doświadczenia „ja” jako całości cielesno-przestrzennej. (Logos i ethos, Rozprawy filozoficzne). Kraków: Polskie Towarzystwo Teologiczne.

WALKER, Margaret U. 1991. „Moral Luck and the Virtues of Impure Agency”. W: Moral Luck, red. Daniel Statman, 235-250. Albany: State University of New York Press.

Williams, Bernard. 1991. „Postscript”. W: Moral Luck, red. Daniel Statman, 251-258. Albany: State University of New York Press, 1991.

WiLliams, Bernard. 1999a. „Działania dobrowolne i odpowiedzialne podmioty”. W: Ile wolności powinna mieć wola? I inne eseje z filozofii moralnej. Przełożyli Tadeusz Baszniak, Tomasz Duliński i Michał Szczubiałka, 197-214. Warszawa: Fundacja Aletheia.

Williams, Bernard. 1999b. „Traf moralny”. W: Ile wolności powinna mieć wola? I inne eseje z filozofii moralnej. Przełożyli Tadeusz Baszniak, Tomasz Duliński i Michał Szczubiałka, 215-238. Warszawa: Fundacja Aletheia.

WoJTYŁA, Karol. 1994. „Osoba i czyn”. W: Osoba i czyn oraz inne studia antropologiczne. Lublin: Towarzystwo Naukowe KUL.

Wolf, Susan. 2001. „The Moral of Moral Luck”. Philosophic Exchange. 31, issue 1: 4-19.

WORONIECKI, Jacek. 1986. Katolicka etyka wychowawcza. T. I: Etyka ogólna. Lublin: Redakcja Wydawnictw KUL.

\section{PROBLEM ODPOWIEDZIALNOŚCI ZA PRZYPADKOWE SKUTKI DZIAŁANIA}

Streszczenie

W artykule bronię tezy, że podmiot, który spowodował niezamierzoną stratę, powinien wziąć za nią odpowiedzialność. Odpowiedzialność ta nie jest wynikiem zaciagniętej przez podmiot winy, nie jest także wyłącznie wyrazem jego wrażliwości na cudzą krzywdę, ale ma swoje obiektywne racje. Działający człowiek doświadcza jedności swojej podmiotowości zarówno wtedy, gdy jest dobrowolnym sprawcą działania, jak i wtedy, gdy działanie to przyczynia się do zaistnienia przypadko- 
wych skutków. Podmiot bowiem jest nie tylko autonomicznym sprawcą, ale także kimś, kto przez konstytuującą go cielesność jest podatny na wpływ rozmaitych czynników przypadkowych, nieprzewidzianych. Aby zachować swoją integralność, podmiot zobowiązany jest do uznania swojej relacji do spowodowanej krzywdy. Racje wzięcia odpowiedzialności za przypadkowe skutki działania odwołują się nie tylko do struktury podmiotu, ale także do samego działania i jego relacji do działającego. Zagadnienia te zostały podjęte w dwóch pierwszych paragrafach artykułu. Ostatnia część artykułu prezentuje istotę obowiązku wzięcia odpowiedzialności za spowodowaną stratę. Taka odpowiedzialność nie zależy od tego, co bezpośrednio leżało w zakresie sprawczości podmiotu, ale dotyczy tego, co należy do półcienia tejże sprawczości. Podmiot poprzez akt woli może uczynić siebie odpowiedzialnym za to, co się stało. Akt wzięcia odpowiedzialności obejmuje takie zachowania, jak wyjaśnienie, przeprosiny, pomoc.

\section{THE PROBLEM OF RESPONSIBILITY FOR ACCIDENTAL EFFECTS OF THE ACTION}

\section{Su m m a r y}

In the paper, I defend the claim that agent who caused unintentional loss should take responsibility for it. Such kind of responsibility is neither a result of being guilty, being moral responsible for the loss, nor is just the expression of one's sensitivity to other people's hurt, but it has proper objective reasons. Human being experiences unity of his agency both in intentional actions and in actions which result in unintended harm. Moral agent is not only autonomous author of the action but also, through his corporeality, is somebody vulnerable to influence of accidental, unintended factors. In order to preserve personal integrity agent is obliged to admit the relation between his action and caused harm. Reasons to take responsibility for unintended results of action do not only relate to structure of human agency, but also relate to the structure of action itself and its relation to acting person. These issues are presented in two first paragraphs of the article. Characteristic features of obligation to take responsibility for unintended loss is presented in the last part of the article. Such responsibility is not a matter of voluntary agency, does not lie in the core of one's agency but concerns what belong to "penumbra of agency." Agent through act of his will makes himself responsible. Act of taking responsibility encompasses such behaviours like explanation, apology, help.

Słowa kluczowe: działanie; podmiot działania; skutki działania; skutki niedobrowolne; odpowiedzialność; natura działającego podmiotu; podmiotowa tożsamość; relacja przyczynowa.

Key words: action; subject of action; effects of action; involuntary effects; responsibility; nature of the acting subject; subjective identity; causal relationship.

Information about Author: ANNA KRAJEWSKA, PhD - John Paul II Catholic University of Lublin, Faculty of Philosophy, Institute of Theoretical Philosophy, Department of Particular Ethics; address for correspondence: Al. Racławickie 14, 20-950 Lublin; e-mail: anna.krajewska@op.pl; ORCID: https://orcid.org/0000-0003-2795-1263. 
